\title{
Optimizing the Efficiency of Solar Cells based on GaAs
}

\author{
Sadek Khellaf and Abdelhamid Ounissi \\ Electronics department, University of Batna, Algeria \\ sadkh05@gmail.com
}

\begin{abstract}
Nowadays thin-film solar cells are increasingly used mainly because of their low cost. In recent decades the performance of these cells were significantly improved. In this work, we simulated a solar cell type GaAs using software (PC1D) to analyze certain parameters, in particular the properties of the window layer, base, emitter and BSF layer (thickness, doping ...), these parameters play a crucial role in the performance of the cell, and to optimize them, we studied their influence on the photovoltaic solar cell sizes. In order to highlight the importance of depositing a layer window type Ga 1-x Al x on GaAs solar cells, a comparison between two cells, one with no window layer, the other with a layer window, was made. The energy efficiency is increased from 24.9 registered in a cell\% to $26.7 \%$ for GaAs cell Gal-x Al x As / GaAs.
\end{abstract}

Keywords: Solar Cell, Heterojunction, Yield, Layer Window, BSF layer, GaAs, PC1D

\section{Introduction}

In recent years, solar cells based on gallium arsenide have been widely used, particularly for space applications, and this owing to their high efficiency and a low degradation in the face of irradiation space. However, a significant problem precluded the development of GaAs solar cells, namely the rate of surface recombination. This is why the performance achieved for the first solar cell was only about 10\% [1-2]. This problem was partially solved by growing a layer of $\mathrm{Ga}_{1-\mathrm{x}} \mathrm{Al}_{\mathrm{x}}$ on the surface of GaAs [3]. The two materials having similar crystal parameters, few defects and the recombination centers may exist in the interface between the two semiconductors. [4] Thus the performance of GaAs cells exceeded $20 \%$ the first time in the late 70 s when Woodall and Hovel fabricated cells to hetero structures with a yield of $22 \%$ [5]. Nowadays, these solar cells have achieved efficiencies of around 20-25\% [6-7]. The solar cell that has been studied, is a structure nnp: $\mathrm{Ga}_{1-\mathrm{x}} \mathrm{Al}_{\mathrm{x}}(\mathrm{n})-\mathrm{GaAs}(\mathrm{n})-\mathrm{GaAs}(\mathrm{p})-\mathrm{GaAs}(\mathrm{p})$, for the highly efficient photovoltaic conversion, and for the reduction of and the series resistance of the surface recombination velocity attributed to the use of the heterojunction across avant.Pour it was used a one-dimensional numerical simulation software PC1D (personal computer onedimensional).

\section{Presentation of the Structure}

The appropriate structure is comprised primarily of a cell $\mathrm{np}$ GaAs based on what is deposited a layer of n-type window $\mathrm{Ga}_{0.3} \mathrm{Al}_{0.7} \mathrm{As}$. Between the substrate and the cell is inserted a layer BSF (Back Surface Field) doped p+, which has the function of creating an electric field delayed rear face, thereby lowering the effective value of the recombination rate for and hence improve the electrical characteristics of the cell. A diagram of the structure illustrated in Figure (1). 


\begin{tabular}{|lr|}
\hline Window & n-Ga $\mathbf{0}_{0.3} \mathrm{Al}_{0.7} \mathrm{As}$ \\
\hline Emitter & $\mathbf{n - G a A s}$ \\
\hline Base & P-GaAs \\
\hline BSF & $\mathbf{P}^{+}$-GaAs \\
\hline Substrate & $\mathbf{P}^{+}$-GaAs \\
\hline
\end{tabular}

Figure 1. Structure of the Solar Cell Study

Note that the structure has been studied under AM1.5 solar spectrum,with $\mathrm{P}=100$ $\mathrm{mW} / \mathrm{cm}^{2}$, and at room temperature $\mathrm{T}=300 \mathrm{~K}$. Measurements of photovoltaic parameters were performed in the case of a zero series resistance and larger shunt resistance infinitely.

\subsection{Current Density of Short Circuit}

Basically the relations governing the operation of a silicon solar cell are valid for gallium arsenide. The density of the monochromatic photocurrent is given by [8]:

$$
J_{n, p h}\left(X_{1}\right)+J_{p, p h}\left(X_{2}\right)+J_{s c r, p h}(W)
$$

$J_{n, p h}$ : the photocurrent density of the emitor

$\mathrm{J}_{\mathrm{p}, \mathrm{ph}}$ : the photocurrent density of the base

$\mathbf{J}_{\text {scr, ph }}$ : photocurrent density of the space charge zone

$\mathrm{W}$ : the thickness of the space charge zone.

The equations previously photocurrents densities for a given wavelength $(\lambda)$ specific are approximately valid in a narrow band width $(\approx 100 \AA)$. The total photocurrent density can be calculated by summing the densities of the photocurrent by the fraction of $100 \AA$ [9].

$$
J_{p h}=\sum_{i=1}^{65} J_{p h}\left(\lambda_{i}\right) \lambda_{i}=0.24+0.01(i-1)
$$

It should be mentioned that the total current density photo shows the current density Jsc shorting.

\subsection{Open-circuit Voltage}

The dark current density is given by $[10,11]$ :

$$
J_{d}=J_{n, d}\left(X_{1}\right)+J_{p, d}\left(W_{B}\right)+J_{s c r, d}
$$

$\mathrm{J}_{\mathrm{n}, \mathrm{d}}$ : density of the dark current of the emettor

$J_{p, d}$ : density of the dark current of the base 


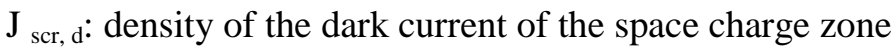
$\mathrm{W}_{\mathrm{B}}$ : the thickness of the neutral zone near the base.

The open circuit voltage is calculated using the feature:

$$
\begin{aligned}
& J=J_{s c r}-J_{d}(V)=0 \\
& V=V_{o c}
\end{aligned}
$$

2.3. Form Factor and photovoltaic conversion efficiency

$$
\begin{gathered}
P=J \cdot V=\left(J_{s c}-J_{d}\right) \cdot V \\
P_{m}=J_{m} \cdot V_{m}=J_{s c}\left[V_{o c}-V_{T}\left(1+\ln \left(1+V_{m} / V_{T}\right)\right)\right] \\
V_{m}=V_{o v}-V_{T} \cdot \ln \left(1+V_{m} / V_{T}\right) \\
F F=\frac{J_{m} \cdot V_{m}}{J_{s c} \cdot V_{o c}} \\
\eta=\frac{P_{m}}{P_{i n}}
\end{gathered}
$$

P: power output,

$\mathrm{P}_{\mathrm{m}}$ : maximum power,

$\mathrm{V}_{\mathrm{m}}$ : maximum voltage,

$\mathrm{J}_{\mathrm{m}}$ : maximum current density,

$\mathrm{V}_{\mathrm{T}}$ : thermal potential,

FF: form factor,

$\eta$ : photovoltaic conversion efficiency,

$\mathrm{P}_{\mathrm{in}}=100 \mathrm{~mW} / \mathrm{cm}^{2}$ : incident power on condition AM1.5.

\section{Optimization Technique}

By optimizing the main problem is as follows:

$$
\mathrm{F}\left(\mathrm{X}_{1}, \mathrm{X}_{2}, \ldots, \mathrm{X}_{\mathrm{N}}\right) \text { rendementphotovoltaique }
$$

Optimize the function:

$$
\mathrm{G}_{\mathrm{k}}\left(\mathrm{X}_{1}, \mathrm{X}_{2}, \ldots, \mathrm{X}_{\mathrm{N}}\right) \text { variation range }
$$

Table 1. Range Structure Parameters

\begin{tabular}{|l|c|}
\hline \multicolumn{1}{|c|}{ Variables } & Range \\
\hline $\mathrm{X}_{1}=$ doping window $\left(\mathrm{cm}^{-3}\right)$ & {$\left[10^{14}-10^{19}\right]$} \\
$\mathrm{X}_{2}=$ doping of the emitter $\left(\mathrm{cm}^{-3}\right)$ & {$\left[10^{14}-10^{19}\right]$} \\
$\mathrm{X}_{3}=$ doping of the base $\left(\mathrm{cm}^{-3}\right)$ & {$\left[10^{14}-10^{19}\right]$} \\
$\mathrm{X}_{4}=$ doping BSF $\left(\mathrm{cm}^{-3}\right)$ & {$\left[10^{14}-10^{19}\right]$} \\
$\mathrm{X}_{5}=$ thickness of the window (um) & {$[0-10]$} \\
$\mathrm{X}_{6}=$ thickness of the emitter (um) & {$[0-10]$} \\
$\mathrm{X}_{7}=$ base thickness (um) & {$[0-10]$} \\
$\mathrm{X}_{8}=$ BSF thickness (um) & {$[0-10]$} \\
\end{tabular}




\section{Results}

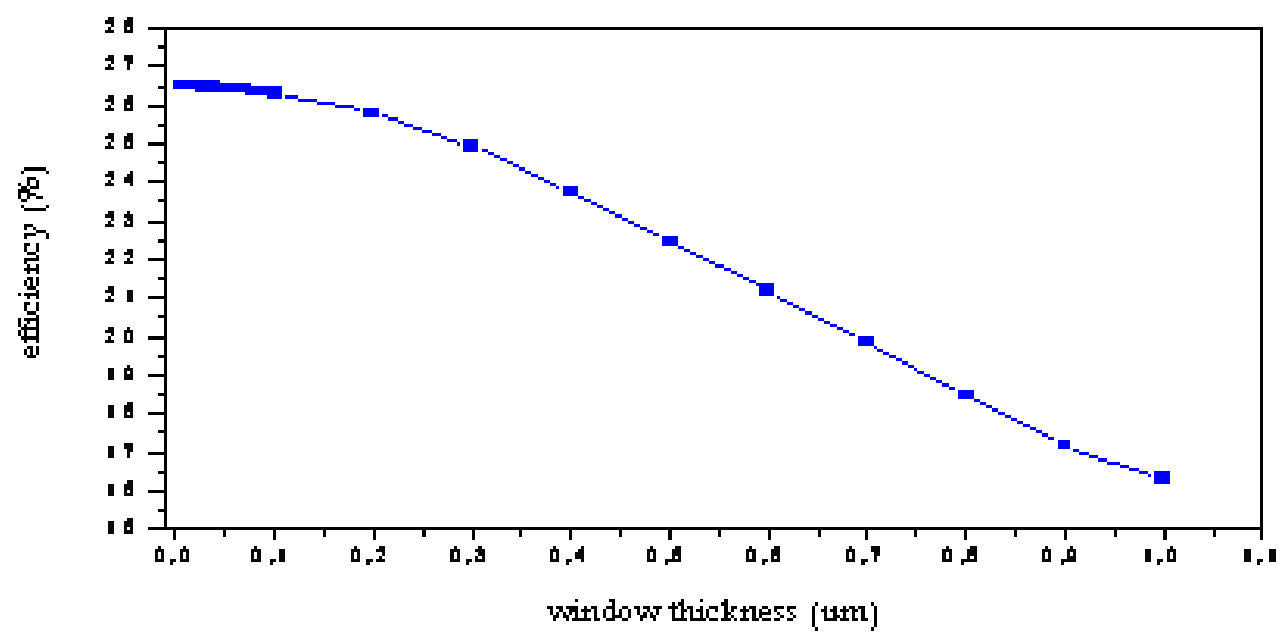

Figure 2. Change in Performance Depending on the Thickness of the Window Layer

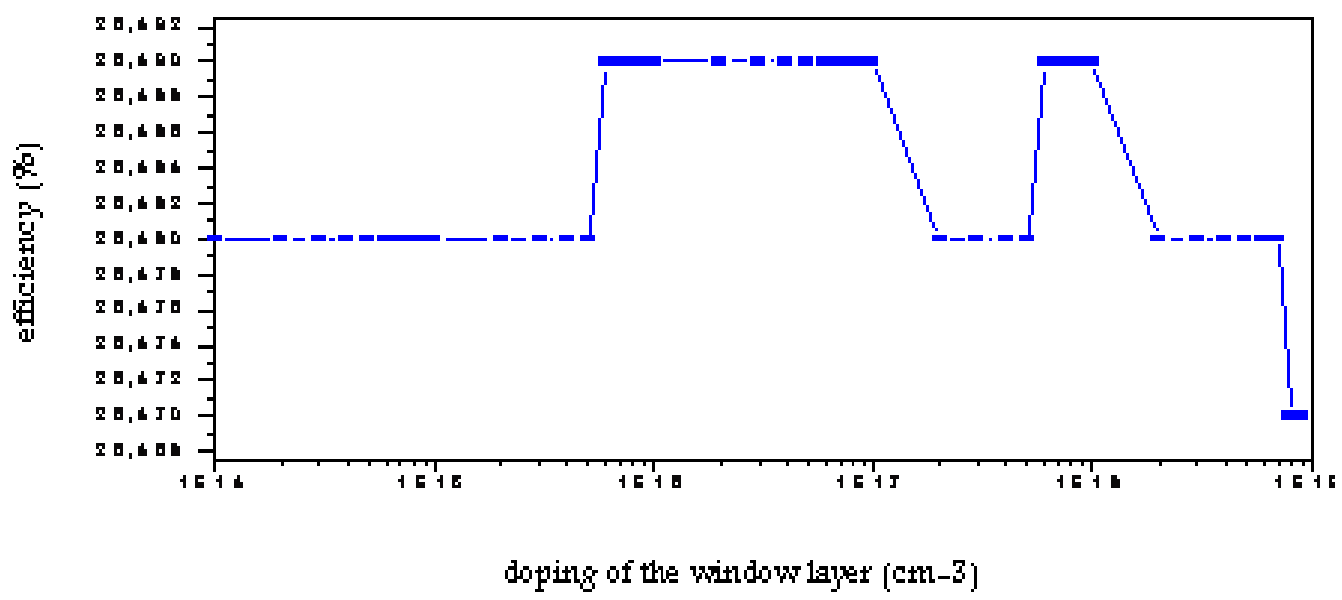

Figure 3. Variation in Performance against Doping the Layer Window

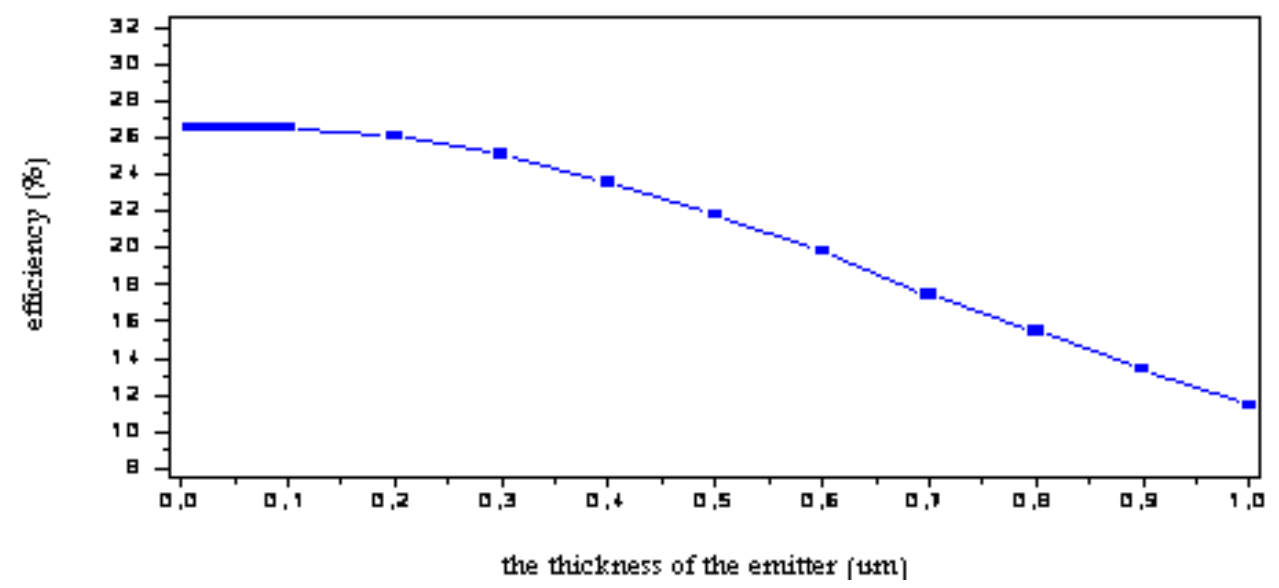

Figure 4. Change in Performance Depending on the Thickness of the Emitter 


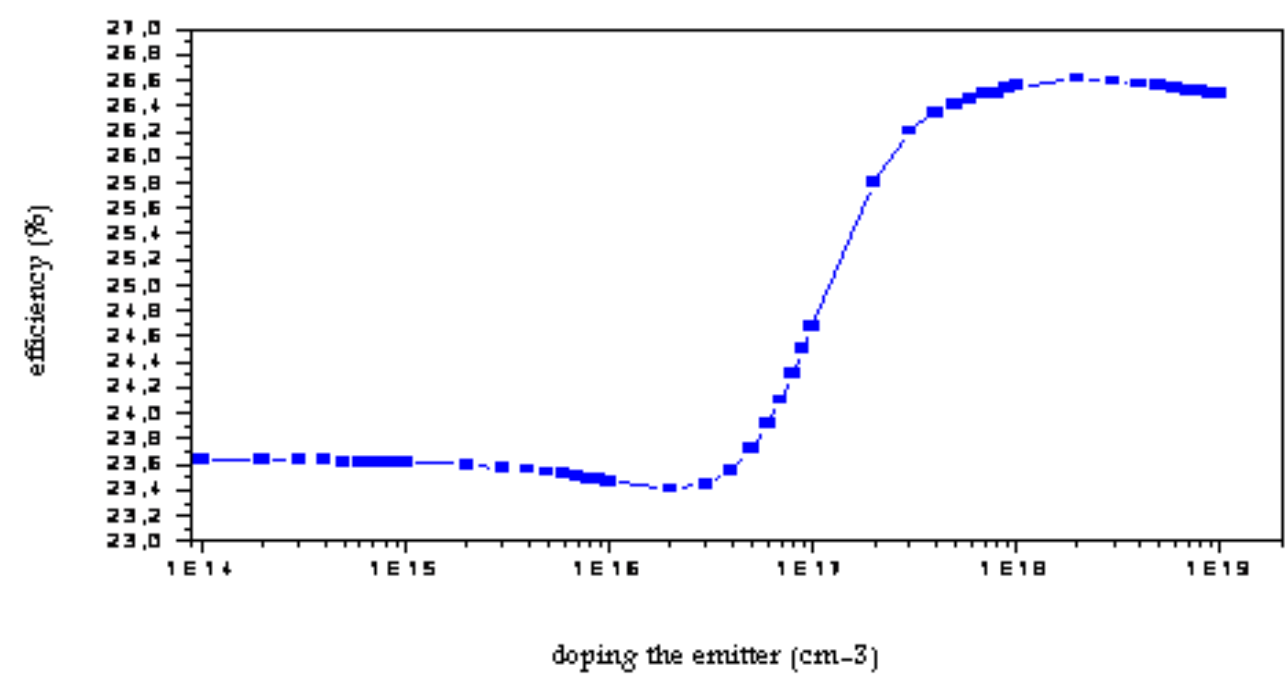

Figure 5. Variation in Performance against Doping of the Emitter

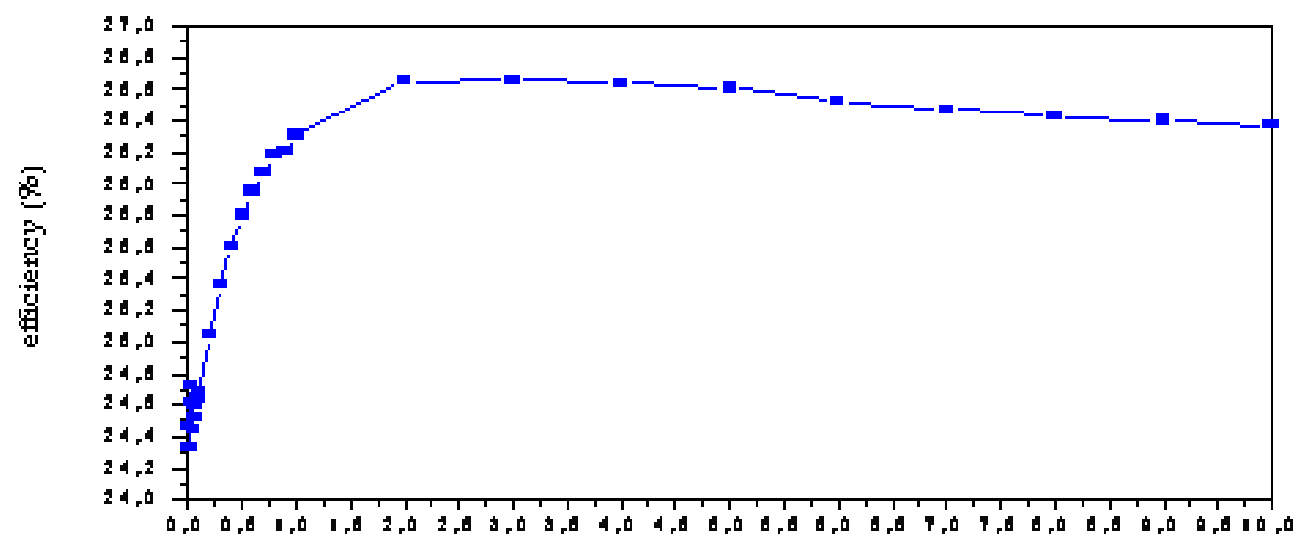

the thickness of the base (um)

Figure 6. Change in Performance Depending on the Thickness of the Base

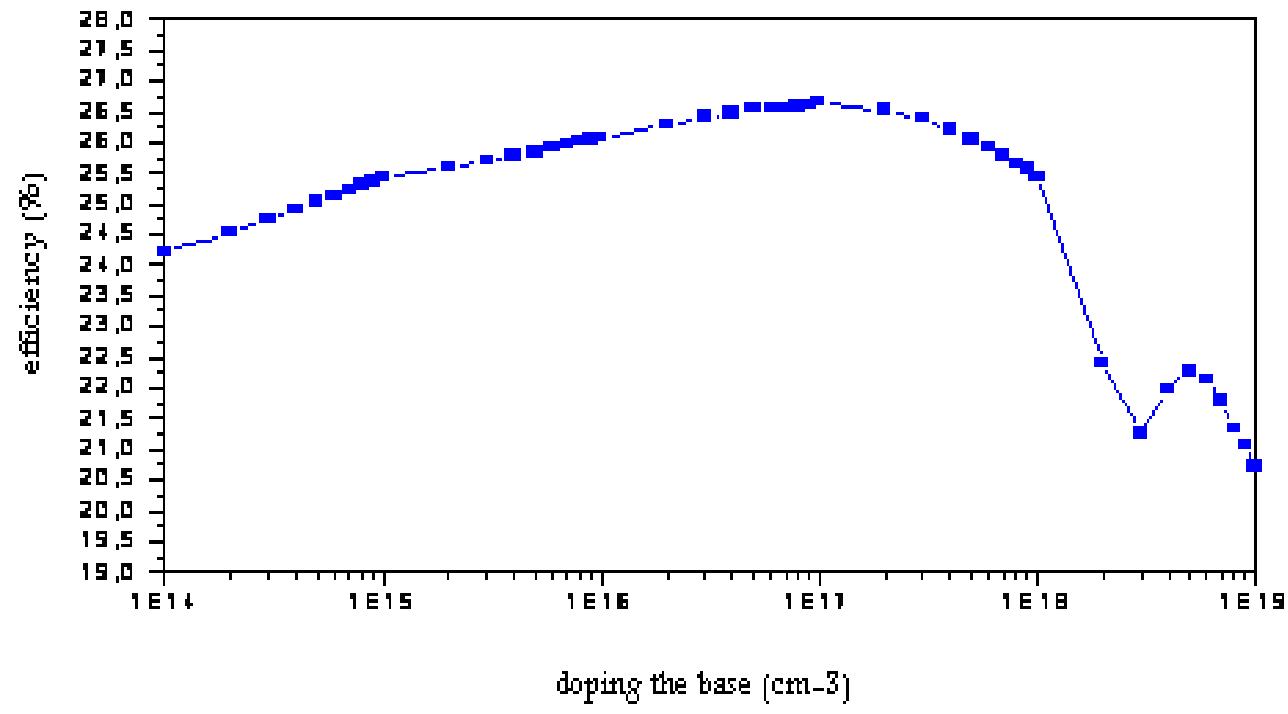

Figure 7. Variation in Performance against Doping Base 


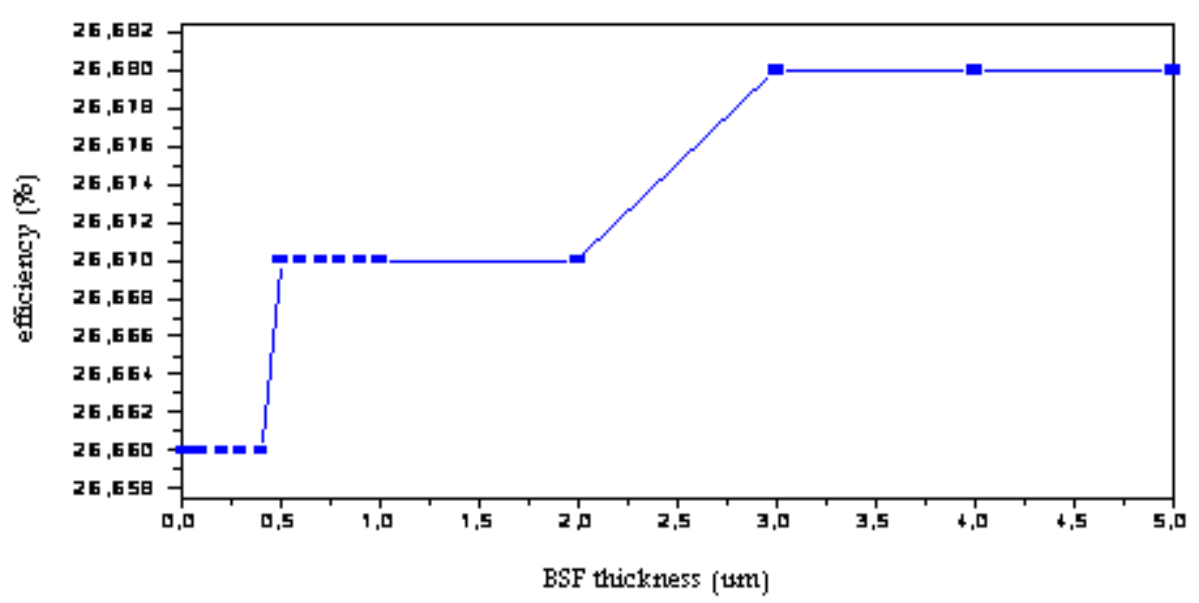

Figure 8. Change in Performance Depending on the BSF Thickness

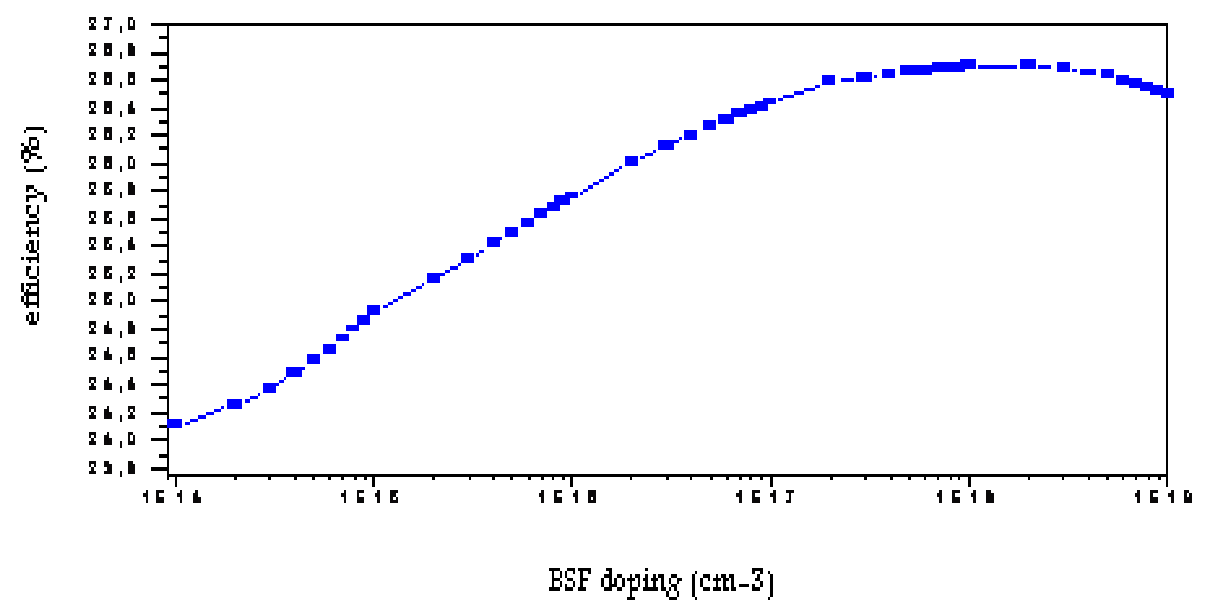

Figure 9. Variation of Performance against Doping BSF

Table 2. Results of Our Optimization

\begin{tabular}{|c|c|c|}
\hline Parameters & Heterojunctio cell & Homojunction cell \\
\hline $\mathrm{N}_{\text {window }}\left(\mathrm{cm}^{3}\right)$ & $10^{18}$ & $10^{17}$ \\
$\mathrm{P}_{\text {Base }}\left(\mathrm{cm}^{3}\right)$ & $10^{17}$ & $2.10^{18}$ \\
$\mathrm{~N}_{\text {emitter }}\left(\mathrm{cm}^{3}\right)$ & $2.10^{18}$ & $2.10^{18}$ \\
$\mathrm{P}_{\mathrm{BSF}}\left(\mathrm{cm}^{3}\right)$ & $2.10^{18}$ & \\
$\mathrm{X}_{\text {window }}(\mathrm{um})$ & 0.01 & 3 \\
$\mathrm{X}_{\text {Base }}\left(\mathrm{cm}^{3}\right)$ & 3 & 0.04 \\
$\mathrm{X}_{\text {emitter }}\left(\mathrm{cm}^{3}\right)$ & 0.04 & 3 \\
$\mathrm{X}_{\text {BSF }}\left(\mathrm{cm}^{3}\right)$ & 3 & 29.9 \\
$\mathrm{I}_{\mathrm{sc}}(\mathrm{mA} / \mathrm{cm})$ & 31.2 & 0.9708 \\
$\mathrm{~V}_{\text {oc }}(\mathrm{V})$ & 0.9975 & 85.79 \\
$\mathrm{FF}(\%)$ & 85.79 & $\mathbf{2 4 . 9}$ \\
$\eta(\%)$ & $\mathbf{2 6 . 7}$ & \\
\hline
\end{tabular}




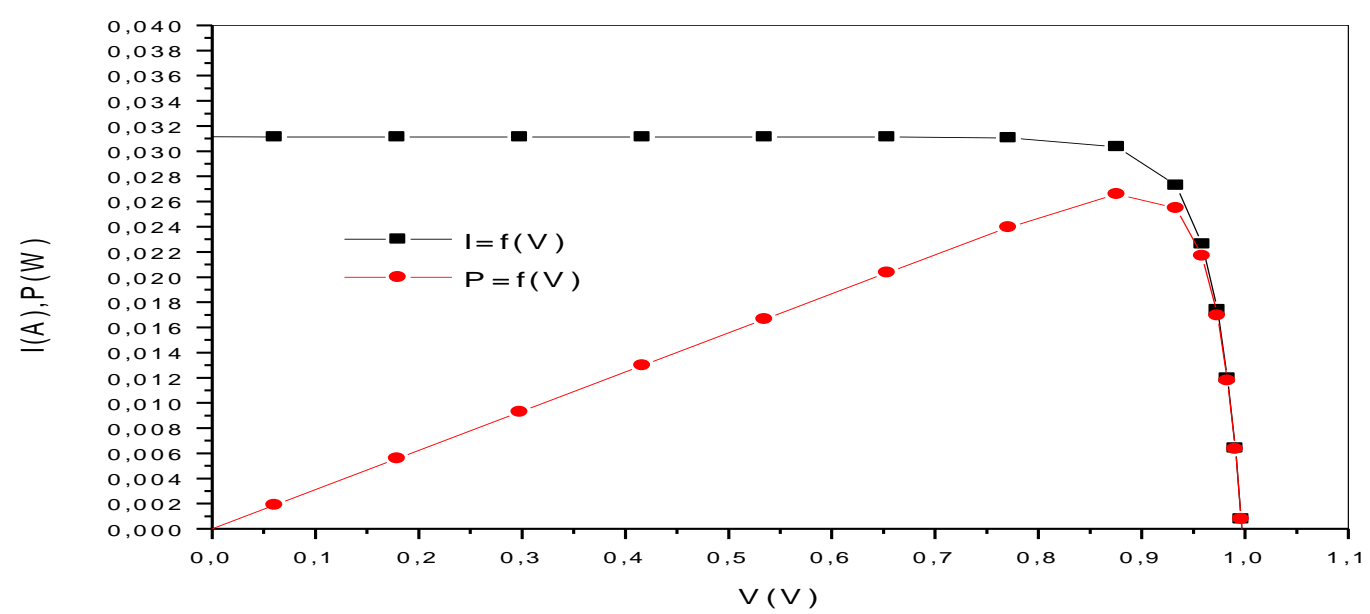

Figure 10. I (V) and P (V) Characteristics of the Heterojunction Cell based on GaAs

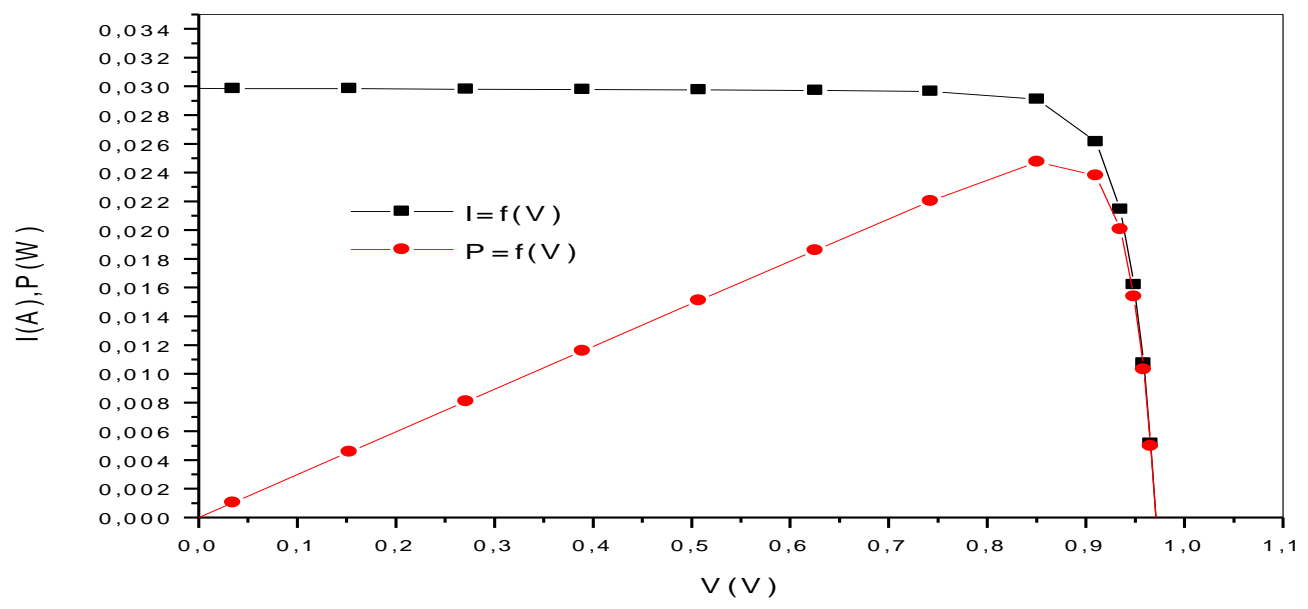

Figure 11. I (V) and P (V) Characteristics of the Homojunction Cell based on GaAs

\section{Conclusion}

We were interested to show the influence of the thickness and doping of the window layer, the emitter, base, BSF layer and the substrate on the photovoltaic parameters of the cells and heterojunction homojonctiona GaAs.

The optimum conditions to obtain the best conversion efficiencies are:

\section{For the heterojunction cell:}

$X_{\mathrm{w}}=0.01 \mathrm{um}, \mathrm{N}_{\mathrm{w}}=10^{18} \mathrm{~cm}-3, \mathrm{X}_{\mathrm{E}}=0.04 \mathrm{um}, \mathrm{N}_{\mathrm{E}}=2.10^{18}$ $\mathrm{cm}^{-3}, \mathrm{X}_{\mathrm{B}}=3 \mathrm{um}, \mathrm{P}_{\mathrm{B}}=10^{17} \mathrm{~cm}^{-3}, \mathrm{X}_{\mathrm{BSF}}=3 \mathrm{um}$ and $\mathrm{P}_{\mathrm{BSF}}=2.10^{18} \mathrm{~cm}-3$

2. For the homojunction cell:

${ }^{3}, \mathrm{X}_{\mathrm{BSF}}=3 \mathrm{um}$ and $\mathrm{P}_{\mathrm{BSF}}=2.10^{18} \mathrm{~cm}_{\mathrm{E}}=0$

$$
X_{E}=0.04 \mathrm{um}, N_{E}=2.10^{18} \mathrm{~cm}^{-3}, X_{B}=3 u m, P_{B}=10^{17} \mathrm{~cm}^{-}
$$


Solar cells based on GaAs give a current density of small short circuit, open circuit voltage greater circuit and perform better than the solar cells based on $\mathrm{Si}$.

\section{References}

[1] S. C. Tsaur, "Theoretical and experimental results for GaAs solar cells", Proceedings of the fourth international symposium on GaAs and related compounds, conference series no. 17, The Institute of Physics, London, U.K., (1972), pp. 156.

[2] C. Hardingham, S. P. Wood., "High efficiency GaAs solar Arrays in Space," GEC Review. vol. 13, no. 3 (1998), pp. 163-171.

[3] J. J. Liou and W. W. Wong, "Comparison and optimization of the performance of Si and GaAs solar cells," Solar Energy Materials and Solar Cells, vol. 28, no. 1, (1992), pp. 9-28.

[4] J. M. Woodall, H. J. Hovel, "High efficiency Ga1-xAlxAs-GaAs solar cells," Solar Energy Materials and Solar Cells, vol. 29, no. 2-3, (1990), pp. 167-172.

[5] M. E. Klausmeier-Brown, "Status, Prospects and Economics of Terrestrial Single Junction GaAs Concentrator Cells," Solar Cells and their Applications, Wiley, New York, (1995).

[6] K. Barnham, J. Barnes, G. Haarpainter, J. Nelson, M. Paxman, T. Foxon and J. Roberts, "Quantum-Well Solar Cells," Materials Research Society Bulletin, Pittsburg, (1993), pp. 51-55.

[7] S. Khelifi et A. Belghachi, "The Role of the window layer in the solar cell performance of GaAs," Laboratory of Physics of Semiconductor Devices, University Center of Bechar,algeria.

[8] H. J. Hovel, B. O. seraphin, "SolarCells," Semiconductors and Semimetals, vol. 1, (1975).

[9] R. Houlstrom, R. Bird and C. Riordan, "Solar Cells," vol. 15, (1985), pp. 365.

[10] M. P. Godlowski, C. R. Baraona and H. W. Brandhorst Jr, "Low-high Junction Theory Applied to Solar Cells," Proc. 10 $0^{\text {th }}$ Photovoltaic Specialist Conference, New York, (1973).

[11] J.J. Liou, "Physical Models for Predicting the Performances of Si/Si, AlGaAs/GaAs and Si/SiGe Solar Cells," Solar Energy Materials and Solar Cells, vol. 29, no. 3, (1993), pp. 261-276. 